\title{
Level of Faecal Coliform Contamination of Drinking Water Sources and Its Associated Risk Factors in Rural Settings of North Gondar Zone, Ethiopia: A Cross-Sectional Community Based Study
}

\author{
Atalay Getachew $^{1 *}$, Alebachew Tadie ${ }^{2}$, Daniel Haile Chercos ${ }^{1}$, Tadesse Guadu ${ }^{1}$
}

\section{OPEN ACCESS}

Citation: Atalay Getachew, Alebachew Tadie, Daniel Haile Chercos, Tadesse Guadu. Level of Faecal Coliform Contamination of Drinking Water Sources and Its Associated Risk Factors in Rural Settings of North Gondar Zone, Ethiopia: A Cross-Sectional Community Based Study. Ethiop J Sci. 2018;28(2):227.

doi:http://dx.doi.org/10.4314/ejhs.v28i2.14 Received: November 12, 2017

Accepted: November 14, 2017

Published: March 1, 2018

Copyright: (C) 2018 Atalay Getachew., et al. This is an open access article distributed under the terms of the Creative Commons Attribution License, which permits unrestricted use, distribution, and reproduction in any medium, provided the original author and source are credited. Funding: Nil

Competing Interests: The authors declare that this manuscript was approved by all authors in its form and that no competing interest exists.

Affiliation and Correspondence:

${ }^{1}$ University of Gondar, College of

Medicine and Health Sciences,

Institute of Public Health, Department

of Environmental \& Occupational

Health \& Safety, Gondar, Ethiopia

${ }^{2}$ University of Gondar, College of

Natural and Computational Sciences,

Department of Biology, Gondar,

Ethiopia

*Email: atalayget@gmail.com

\section{ABSTRACT}

BACKGROUND: Today, close to a billion people mostl living in the developing world do not have access to safe and adequate water. Several studies in Ethiopia indicate that the majority of the drinking water sources had coliform count beyond the WHO standard. Therefore, Regular quality control mechanisms need to be in place. The objective of this study is therefore to determine the level of faecal coliform contamination of drinking water and its associated factors in North Gondar Zone, Ethiopia.

METHODS: A community-based cross-sectional study was conducted in rural parts of North Gondar Zone from April to July, 2016. Water samples were taken from water sources using standardized water sampling techniques. Face-to-face interview with structured questionnaires were used to collect socio-economic and behavioral data. Univariate and multivariate analyses were done using logistic regression models.

RESULTS: A total of 736 households participated in the study. The prevalence of positive faecal coliform at water sources in North Gondar Zone was found to be $56.5 \%(n=416)$ with [95\% CI (53-60)]. In multivariate analysis, educational status [(AOR): 0.28, 95\% CI (0.1-0.8], sanitary risk of contamination [AOR): 513, 95\% CI (51-511)] and water shortage experience [AOR: 0.25, 95\% CI (0.12-0.5)] are variables identified as predictors for faecal coliform contamination of water in the source.

CONCLUSION: In this study, the prevalence of positive faecal coliform at water source was high. Educational status, sanitary Risk of contamination at the water source, water shortage experience had significant associations with the presence of faecal coliform in drinking water sources.

KEYWORDS: Water quality, Risk factors, Coliform

\section{INTRODUCTION}

Accesse to safe water and sanitary means of excreta disposal are universal needs and indeed basic human rights; however, many of the world's population lack access to adequate and safe water (1). Moreover, water quality and the risk to waterborne diseases are 
critical public health concerns in many developing countries. Today, close to a billion people mostly living in the developing world do not have access to safe and adequate water (2). In 2012, 1.9 billion people used either an unimproved source or an improved source with faecal contamination (3).

Several studies have confirmed that water related diseases not only remain a leading cause of morbidity and mortality worldwide but that the spectrum of diseases is expanding and the incidence of many water-related microbial disease is increasing (4). Annually, an estimated 4 billion cases of diarrhea, which represented $5.7 \%$ of the global disease burden in the year 2000, occurred (5).

Most of the population of Ethiopia in rural and urban areas does not have access to safe and reliable sanitation facilities (6). Over $60 \%$ of the communicable diseases in Ethiopia are due to poor environmental health conditions arising from unsafe and inadequate water supply, poor hygienic and sanitation practices (7). As a result, people are still dependent on unprotected water sources such as rivers, streams, springs and hand dug wells. Since these sources are open, they are highly susceptible to flood, birds, animal and human contamination (6).

In rural and urban areas, water quality is affected by both point and nonpoint sources of pollution. Some of these sources include sewage discharge, industrial discharge, agricultural run-off, floods and droughts, as well as lack of awareness among end users aspects including hygiene, environment sanitation; storage and disposal need to be considered for the maintenance of water resources (8).

Ensuring the safety of drinking water is a continuous process. In developed countries, drinking water regulations require the monitoring of multiple microbiological and chemical parameters. However, it is well established that the risks associated with the consumption of microbiologically contaminated water are a great concern for the occurrence of different disease like diarrhea (9).

Despite the reduction of the percentage of the population with access to unsafe drinking-water in
Ethiopia by $11 \%$ (10), sveral studies in Ethiopia indicate that the majority of the drinking water sources had coliform count beyond the WHO standard (11-15). Specifically, in North Gondar Zone, the majority of the drinking water sources is either of unacceptable quality or grossly polluted. Thus, rgular quality control mechanisms is vital to ensure the safety of drinking water (14). The objective of this study is therefore to determine the level of faecal coliform contamination of drinking water and its associated factors in North Gondar Zone, Ethiopia.

\section{METHODS}

Study design and area: A community-based cross-sectional study design was conducted in north Gondar administrative Zone from April-July; 2016. Gondar is located $739 \mathrm{~km}$ far from Addis Ababa to the Northwest of Ethiopia. North Gondar is one of the eleven zones in Amhara Regional State. It has 22 administrative woredas (districts). According to the data gained from North Gondar Zonal Health Department, the total projected population in $2015 / 16$ is $3,704,740$. The majority of the populations, $2,920,007(78.8 \%)$ reside in rural areas whereas the rest $784,733(21.2 \%)$ are in urban areas. Moreover, 499,542(13.5\%) of the population are under-five children. According to the reports of the North Gondar Zonal Health Department (2014/15), diarrheal diseases are one of the top ten diseases in North Gondar Zone [Unpublished report].

The source population was all members of North Gondar Zone population in 2016. The study population was randomly selected households.

Sample size and sampling technique: Epi info version 7.1 was used to calculate the sample size based on an assumption that $30 \%$ of households had faecally contaminated drinking water sources (15) with marginal error of $5 \%, 95 \%$ confidence interval, design effect of 2 , accounted for two-stage sampling and non-response rate of $10 \%$. Accordingly, the total sample size included in the study was 736 households. From randomly selected four districts (Dembia, Gondar Zuriya, Chilga and Sanja) of the 22 total districts of North Gondar Zone, multi-staged sampling procedure

DOI: http://dx.doi.org/10.4314/ejhs.v28i2.14 
was employed. Using probability proportional (PPS) to size, the number of households was determined in each district. Then, $25 \%$ of the total kebeles were selected from each district by simple random sampling technique, and systematic sampling technique was applied to select study households.

Data collection procedures and tools: Water samples for bacteriological analysis were collected from the household's drinking water sources. The method of water sample collection from each household water sources was done according to the American Public Health Association (APHA) guidelines for drinking water quality assessment (16). Water samples were analyzed using standardized bacteriological methods for water quality analysis as used by Cheesbrough to determine bacteriological contamination (17). All samples were analyzed for faecal coliform count within 4 hours of sample collection using the membrane filter technique. Faecal coliforms (FC) enumeration was carried out using membrane filtration techniques in which $100 \mathrm{ml}$ of water sample was filtered through the membrane filter (millipore $45 \mu \mathrm{m}$ ). Membrane lauryl sulfate medium that was dispensed on to the absorbent pad was used for bacterial growth medium. Then, the membrane filter with millipore $45 \mu \mathrm{m}$ through which water sample filtered was placed on membrane lauryl sulfate medium in aluminum petridish and was incubated at $44 \pm 0.5^{\circ} \mathrm{C}$ for $18-24$ hours. The yellow colonies were counted as coliforms under microscope.

Face-to-face interview was conducted from structured questionnaires in order to collect socioeconomic and behavioral characteristics. Observations using structured using sanitary survey checklist were conducted by trained professionals to assess the risk of contamination of the drinking water sources.

Data quality control: Training was given for data collectors and supervisors for three days on the procedures, techniques and ways of data collection. Prior to the commencement of the actual data collection process, the data collection tools were pretested on nearby district which is not part of the actual data collection. In addition, continuous and strict supervision was carried out during the data collection process.

Water samples from each household water source were collected in sterilized glass bottles. All water samples were collected by trained laboratory technicians. All sampling bottles were appropriately labeled before the collection of samples. The samples were collected using standardized drinking water sampling techniques. The collected water samples were kept in icebox during transportation put at $4{ }^{\circ} \mathrm{c}$ before analysis in the laboratory. Before analysis, sterilization of required laboratorial equipments and culture medium was carried out. Moreover, to ensure the validity of the analysis, blank samples were analyzed following the same procedure.

Ethical considerations: Ethical clearance was obtained from the University of Gondar. After thoroughly discussing the ultimate purpose and method of the study, a written consent was obtained from Institutional Ethical Committee of the University of Gondar. Then, community consent was obtained from the respective community leaders. The privacy and confidentiality were maintained during interview. Therefore, only coding was included in the data collection tools. In addition, participants in the study that were not willing to take part in the study had full right not to participate.

Data processing and analysis: Data was entered using Epi-Info version 7.1 and analyzed using SPSS statistical package for windows, version 20.0. A P-value of less than 5\% was used to declare association between factors and the dependent variable.

\section{RESULTS}

Socio-demographic characteristics of respondents: From a total of 736 respondents of households who participated, mean $( \pm \mathrm{SD})$ age was $30 \pm 7$ years, and nearly half, 362(49.2\%) respondents were aged between 25-34 year. The majority, 690(93.8\%), of the participants' religion was Orthodox Christianity, and more than half of the respondents $431(58.5 \%)$ were unable to read. Most of the respondents, 693(94.2\%), were married and housewives, 632(85.8\%). The majority, 463(62.9\%), of the respondents had

DOI: http://dx.doi.org/10.4314/ejhs.v28i2.14 
family size of less than five individuals and $423(57.3 \%)$ of the respondents had income less of than 1000 ETB (Table 1).

Table 1: Distribution of socio-demographic characteristics of respondents in North Gondar Zone, 2016 ( $\mathrm{n}=736)$.

\begin{tabular}{llc}
\hline Variables & Number & $\mathbf{\%}$ \\
\hline Source of potable water & & \\
$\quad$ Piped & 396 & 53.8 \\
$\quad$ Open well & 61 & 8.3 \\
$\quad$ Protected well & 184 & 25 \\
$\quad$ Open spring & 72 & 9.8 \\
$\quad$ Protected spring & 6 & 0.8 \\
$\quad$ River & 17 & 2.3 \\
Water shortage experience & & \\
$\quad$ Yes & 461 & 62.6 \\
$\quad$ No & 275 & 37.4 \\
Hand washing facility & & \\
$\quad$ Yes & 392 & 53.3 \\
$\quad$ No & 344 & 46.7 \\
Place of solid waste disposal & & \\
$\quad$ Pit & 168 & 22.8 \\
$\quad$ Open field & 556 & 75.5 \\
$\quad$ Burning & 12 & 1.6 \\
Animals live in the same & & \\
house & & \\
$\quad$ Yes & 173 & 23.5 \\
$\quad$ No & 563 & 76.5 \\
\hline
\end{tabular}

Environmental characteristics of respondents: The majority, 396(53.8\%), of the respondents used pipe water as source of potable water, and only $392(53.3 \%)$ of the respondents had hand washing facility. The majority, 556(75.5\%), of the respondents used open field as way of disposing solid waste, and $173(23.5 \%)$ of the participants livedwith animals in the household (Table 2).

Behavioral characteristics of respondents: The majorly of the respondent, 652(88.6\%, doid not use any type of household water treatment techniques. All respondents washed their hands in the previous 24 hours, and less than $1 \%$ of respondents washed their hands after visiting toilet as well as cleaning child's bottoms. More than half, 425(57.7\%), of the participants washed their hand with soap and water, and 315(42.8\%), of water sources had high risks of contaminations (Table 3).
Table 2: Distribution of household environmental characteristics of respondents, North Gondar Zone, 2016 ( $\mathrm{n}=736)$.

\begin{tabular}{|c|c|c|}
\hline Variables & Number & $\%$ \\
\hline \multicolumn{3}{|l|}{ Age } \\
\hline$<15$ & 3 & 0.4 \\
\hline $15-24$ & 149 & 20.2 \\
\hline $25-34$ & 362 & 49.2 \\
\hline$>35$ & 222 & 30.2 \\
\hline \multicolumn{3}{|l|}{ Religion of parents } \\
\hline Orthodox & 690 & 93.8 \\
\hline Protestant & 6 & 0.8 \\
\hline Muslim & 40 & 5.4 \\
\hline \multicolumn{3}{|l|}{ Educational level } \\
\hline Illiterate & 431 & 58.6 \\
\hline Read and write & 62 & 8.4 \\
\hline $1-8$ & 135 & 18.3 \\
\hline $9-12$ & 108 & 14.7 \\
\hline \multicolumn{3}{|c|}{ Occupation of the mother } \\
\hline \multicolumn{3}{|c|}{ Government employee } \\
\hline Housewife & 24 & 3.3 \\
\hline Merchant & 632 & 85.9 \\
\hline \multirow[t]{2}{*}{ Farmer } & 35 & 4.8 \\
\hline & 45 & 6.1 \\
\hline \multicolumn{3}{|l|}{ Marital Status } \\
\hline Married & 693 & 94.2 \\
\hline Single & 2 & 0.3 \\
\hline Divorced & 35 & 4.8 \\
\hline Widowed & 8 & 0.8 \\
\hline \multicolumn{3}{|l|}{ Family size } \\
\hline$\leq 5$ & 463 & 62.9 \\
\hline$>5$ & 273 & 37.1 \\
\hline \multicolumn{3}{|l|}{ Income } \\
\hline$<1000$ Birr & 423 & 57.5 \\
\hline 1000-2000 Birr & 284 & 38.6 \\
\hline >2000 Birr & 29 & 3.9 \\
\hline
\end{tabular}

Level of faecal contamination of drinking water sources: The prevalence of positive faecal coliform from the water sample taken from drinking water source in North Gondar Zone was found to be $56.5 \%(n=416)$ with [95\% CI (5360)]. After the bacteriological analysis, the faecal coliform load was quantitatively and qualitatively categorized to determine the risk level based on WHO classification (18). In this study, less than half, 320(43.5\%), of the households' water source

DOI: http://dx.doi.org/10.4314/ejhs.v28i2.14 
was free from faecal coliform (no risk of contamination) (Table 4).

Factors associated with presence of faecal coliform in drinking water sources: In the univariable binary logistic regression analysis, educational status, religion, income status, place of solid waste pit, risk of contamination at the water source, presence of latrine facility, water shortage experience had a $\mathrm{p}$-value less than 0.2 and further analyzed by multivariable binary logistic regression. Finally, Educational status, sanitary risk of contamination at the water source and water shortage experience had significant associations with the presence of faecal coliform in drinking water sources.

Table 3: Distribution of behavioral characteristics of respondents in North Gondar Zone, 2016 ( $n=736)$.

\begin{tabular}{lcc}
\hline Variables & Number & Percent (\%) \\
\hline Type of household water treatment & & 1.8 \\
Boiling & 13 & 2.6 \\
Filtering & 19 & 5.4 \\
Use of chemicals & 40 & 1.6 \\
Allowing water to settle & 12 & 88.6 \\
No treatment & 652 & \\
Hand washing History in the & & 100 \\
previous 24 hrs & 736 & 0 \\
Yes & 0 & 62.6 \\
No & 461 & 3.4 \\
Time of hand washing & 25 & 0.7 \\
Before food preparation/eating & 5 & 0.7 \\
After eating & 5 & 32.6 \\
After visiting latrine & 240 & \\
After cleaning of child bottom & & 57.7 \\
Wash at all conditions & 425 & 9.8 \\
Materials to wash hands & 72 & 32.5 \\
Soap and water & 239 & \\
Ash and water & & 28 \\
Only water & 206 & 42.7 \\
Risk contaminations at household storage & 314 & 26.9 \\
Low & 198 & 2.4 \\
Medium & 18 & 43.5 \\
High & 320 & 4.9 \\
Very high & 36 & 8.8 \\
Risk contaminations at source & 315 & \\
Low & 65 & \\
Medium & & \\
High & & \\
Very high & & \\
\hline
\end{tabular}

Table 4: Level of faecal contamination of drinking water sources in North Gondar zone, Ethiopia, 2016.

\begin{tabular}{lll}
\hline Risk (FC counts (cfu/100ml)) & Frequency & Percentage \\
\hline No risk $(0)$ & 320 & 43.5 \\
Low $(1-10)$ & 36 & 4.9 \\
Intermediate $(11-100)$ & 315 & 42.8 \\
High $(101-1000)$ & 65 & 8.8 \\
Very high $(1000+)$ & 0 & 0 \\
\hline
\end{tabular}

DOI: http://dx.doi.org/10.4314/ejhs.v28i2.14 
Respondents whose educational status was from grade $9-12$ had $72 \%$ lower chance of faecal coliform contamination in drinking water sources than illiterate respondents [AOR: $0.28,95 \% \mathrm{CI}$ (0.1-0.8] (Table 5). Water sources which had high risk of contamination in sanitary survey had 513 times higher odds of faecal coliform contamination in drinking water sources [AOR: $513,95 \%$ CI (51-511)] than water source which had low risk of contamination in sanitary survey. Moreover, water source which had medium risk of contamination in sanitary survey had 248 times higher odds of faecal coliform contamination in drinking water sources [AOR: 248, 95\%CI (110-562)] than low risk of contamination in sanitary survey (Table 5). Respondents who had no water shortage experience had $75 \%$ lower chance of faecal coliform contamination in drinking water sources [AOR: $0.25,95 \% \mathrm{CI}(0.12-0.5)$ ] compared to their counterparts (Table 5).

Table 5: Multivariable analysis of factors affecting the presence of faecal coliform in drinking water sources in North Gondar Zone, 2016 ( $\mathrm{n}=736)$.

\begin{tabular}{|c|c|c|c|c|}
\hline \multirow[t]{2}{*}{ Variables } & \multicolumn{2}{|c|}{ Presence of coliform at Source } & \multirow{2}{*}{$\begin{array}{c}\text { Crude OR } \\
(95 \% \text { CI })\end{array}$} & \multirow{2}{*}{$\begin{array}{c}\text { Adjusted OR } \\
(95 \% \mathrm{CI})\end{array}$} \\
\hline & Yes & No & & \\
\hline \multicolumn{5}{|l|}{ Educational status } \\
\hline Illiterate & $271(62.9 \%)$ & $160(37.1 \%)$ & 1:00 & 1:00 \\
\hline read and write & $36(58.1 \%)$ & $26(41.9 \%)$ & $0.82(0.48-1.4)$ & $2.32(0.21-24.7)$ \\
\hline $1-8$ & $66(48.9 \%)$ & $69(51.1 \%)$ & $0.5(0.38-0.83)^{*}$ & $0.41(0.13-1.25)$ \\
\hline $9-12$ & $34(45.3 \%)$ & $41(54.7 \%)$ & $0.5(0.3-0.8)^{*}$ & $0.28(0.1-0.8) *$ \\
\hline$>12$ & $9(27.3 \%)$ & $24(72.7 \%)$ & $0.2(0.1-0.5)^{*}$ & $0.32(0.06-1.6)$ \\
\hline \multicolumn{5}{|l|}{ Religion } \\
\hline Orthodox & $407(29 \%)$ & $283(41 \%)$ & 1:00 & 1:00 \\
\hline Protestant & $1(16.7 \%)$ & $5(83.3 \%)$ & $5.7(2.6-12.6)$ & $2.3(0.22-24.7)$ \\
\hline Muslim & $8(20 \%)$ & $32(80 \%)$ & $0.8(0.02-7.8)$ & $0.03(0.008-1.09)$ \\
\hline \multicolumn{5}{|l|}{ Income status } \\
\hline Up to $1000 \mathrm{ETB}$ & $260(61.5 \%)$ & $163(38.5 \%)$ & $1: 00$ & $1: 00$ \\
\hline $1001-2000$ ЕТВ & $148(52.1 \%)$ & $136(47.9 \%)$ & $0.68(0.5-0.9)$ & $0.78(0.4-1.5)$ \\
\hline >2001 ETB & $8(27.6 \%)$ & $21(72.1 \%)$ & $0.24(0.1-0.5)^{*}$ & $0.3(0.07-1.3)$ \\
\hline \multicolumn{5}{|l|}{ Place of solid waste } \\
\hline Pit & $88(52.4 \%)$ & $80(47.6 \%)$ & 1:00 & $1: 00$ \\
\hline Open field & $325(58.5 \%)$ & $231(41.5 \%)$ & $1.3(0.9-1.8)$ & $1.8(0.8-3.9)$ \\
\hline Burning & $3(25 \%)$ & $9(75 \%)$ & $0.3(008-1.15)$ & $0.23(0.01-4.2)$ \\
\hline \multicolumn{5}{|c|}{$\begin{array}{l}\text { Risk of contamination at } \\
\text { the water source }\end{array}$} \\
\hline Low risk & $28(9.2 \%)$ & $278(90.8 \%)$ & $1: 00$ & $1: 00$ \\
\hline Medium risk & $315(88.5 \%)$ & $41(11.5 \%)$ & $76.3(45-126)^{* *}$ & $248(110-562) * *$ \\
\hline High risk & 73(93.6\%) & $1(1.4 \%)$ & $724.8(97-554)^{* *}$ & $513(51-511) * *$ \\
\hline \multicolumn{5}{|c|}{ Presence of Latrine facility } \\
\hline Yes & $303(62.9 \%)$ & $179(37.1 \%)$ & $0.48(0.35-0.65)^{*}$ & $0.29(0.08-1.04)$ \\
\hline No & $113(44.5 \%)$ & $141(55.5 \%)$ & $1: 00$ & $1: 00$ \\
\hline \multicolumn{5}{|c|}{ Water shortage experience } \\
\hline Yes & $298(64.6 \%)$ & $163(35.4 \%)$ & 1:00 & $1: 00$ \\
\hline No & $118(42.9 \%)$ & $157(57.1 \%)$ & $0.41(0.3-0.5)^{* *}$ & $0.25(0.12-0.5) *$ \\
\hline
\end{tabular}

Note: $1.00=$ Reference, ${ }^{*}$ Significant at $\mathrm{P}$ value $<0.05,{ }^{*}$ Significant at $\mathrm{P}$ value $<0.01$

DOI: http://dx.doi.org/10.4314/ejhs.v28i2.14 


\section{DISCUSSION}

In this study, the prevalence of positive faecal coliform from the water sample taken from drinking water source in North Gondar Zone is found to be high $(56.5 \%)$. This is contrary to WHO guideline for drinking water quality (4). However, this finding is less than studies done in North Showa Zone, Ethiopia (11), Southwest Ethiopia (19), Shashemane Rural District, Ethiopia (20) and Nigeria (21). This discrepancy might be due to the difference in the season where the study was conducted and type of water sources used.

Educational status, sanitary risk of contamination at the water source and water shortage experience had significant associations with the presence of faecal coliform in drinking water sources.

Respondents whose educational status was from grade 9-12 had lower chance of drinking water source faecal coliform contamination than illiterate respondents. This is in agreement with studies done in Nepal (22) and in Tanzanian (23). This might be due to awareness of the educated respondents to the risk of faecal coliform contamination.

Regarding water shortage experiences, respondents who had no water shortage experience had lower chance of drinking water source faecal coliform contamination compared to their counterparts. This finding is similar with studies done in Tanzanian (23). It is also consistent with other finding stating that faecal contamination of drinking water is related with intermittent water supply (24). This might be due to contamination of the water source by unhygienic water container and hand because of water scarcity for washing.

Water sources which had high risk of contamination in sanitary survey had 513 times higher odds of faecal coliform contamination in drinking water sources than water source which had low risk of contamination in sanitary survey. Moreover, water source which had medium risk of contamination in sanitary survey had 248 times higher odds of faecal coliform contamination in drinking water sources than low risk of contamination in sanitary survey. This finding is in agreement with studies done in Tehuledere Woreda, Northeast Ethiopia in 2003 (25), Wondo Genet District, Southern Ethiopia (26) and a rural community of Ethiopia (15). This is due to the fact that poor sanitary condition of source water aggravate the risk of contamination with different bacteria.

In conclusion, in this study, the prevalence of positive faecal coliform from the water sample taken from drinking water source in North Gondar Zone is found to be high. Educational status, sanitary risk of contamination at the water source and water shortage experience had significant associations with the presence of faecal coliform in drinking water sources.

\section{ACKNOWLEDGEMENTS}

The authors would like to thank University of Gondar for its financial support. We are also thankful for study participants, data collectors and supervisors for their devotion and full participation.

\section{REFERENCES}

1. WHO/UNICEF. Rapid assessment drinking water quality in the Federal Democratic Republic of Ethiopia, Country Report of Pilot Project Implementation in 2004-2005. WHO, Geneva and UNICEF, New York, 2010.

2. UNICEF/WHO. Progress on drinking water and sanitation: 2012. UNICEF, New York: 2012.

3. Bain R, Cronk R, Hossain R, Bonjour S, Onda K, Wright J, et al. Global assessment of exposure to faecal contamination through drinking water based on a systematic review. Tropical Medicine and International Health. 2014;19 (8):917-27.

4. WHO. Guidelines for drinking water quality. Switzerland, Geneva., 2003.

5. WHO. The World Health Report 2002. Geneva.: 2002.

6. UN-WATER/WWAP. United Nations educational, scientific and cultural organization

DOI: http://dx.doi.org/10.4314/ejhs.v28i2.14 
world water assessment program. . Addis Ababa., 2002.

7. WHO. Water, sanitation and hygiene links to health, facts and figures. . Geneva, 2004.

8. Nitasha K, Sanjiv T. Influences of natural and anthropogenic factors on surface and groundwater quality in rural and urban areas. Frontiers in Life Science. 2014;8(1):23-39.

9. Organization for Economic Co-operation and Development, Assessing Microbial Safety of Drinking Water: Improving Approaches and Methods IWA Publishing: London, 2003

10. Bain RE, Gundry SW, Wright JA, Yang H, Pedley $\mathrm{S}$, Bartram JK. Accounting for water quality in monitoring access to safe drinking-water as part of the Millennium Development Goals: lessons from five countries. Bull World Health Organ. 2012;90(3):228-35A. Epub 2012/03/31.

11. Bulti K F, Melkam D L. Bacteriological quality of drinking tap water in selected districts of north showa zone, Amhara, Ethiopia. Archives of Applied Science Research. 2016;8(6):23-7.

12. Amenu D, Menkir S, Gobena T. Microbiological Quality of Drinking Water Sources in Rural Communities of Dire Dawa Administrative Council. Science, Technology and Arts Research Journal. 2012;1(4):33-7.

13. Yasin M, Ketema T, Bacha K. Physico-chemical and bacteriological quality of drinking water of different sources, Jimma zone, Southwest Ethiopia. BMC research notes. 2015;8:541. Epub 2015/10/07.

14. Mengesha A, Mamo W, Baye G. A survey of bacteriological quality of drinking water in North Gondar. Ethiop J Health Dev. 2004;18(2):112-5.

15. Tsega $\mathrm{N}$, Sahile $\mathrm{S}$, Kibret $M$, Abera $B$. Bacteriological and physico-chemical quality of drinking water sources in a rural community of Ethiopia. African health sciences. 2013;13(4):1156-61. Epub 2014/06/19.

16. APHA-AWWA-WPCF. Standard methods for the examination of water and wastewater APHA American Public Health Association, 1981.

17. Cheesbrough M. Medical laboratory manual for tropical countries. M. Cheesbrough, 14 Bevills
Close, Doddington, Cambridgeshire, PE15 OTT: 1981.

18. WHO. Guidelines for drinking-water quality: . Geneva: 2004.

19. Abera S, Zeyinudin A, Kebede B, Deribew A, Ali $\mathrm{S}$, Zemene E. Bacteriological analysis of drinking water sources. African Journal of Microbiology Research. 2011;5(18):2638-41.

20. Edessa N, Geritu N, Mulugeta K. Microbiological assessment of drinking water with reference to diarrheagenic bacterial pathogens in Shashemane Rural District, Ethiopia. African Journal of Microbiology Research. 2017;11(6):254-63.

21. Shittu OB, Olaitan JO, Amusa TS. PhysicoChemical and Bacteriological Analyses of Water Used for Drinking and Swimming Purposes in Abeokuta, Nigeria. African Journal of Biomedical Research. 2008;11:285-90.

22. Pant PD. Effect of education and household characteristics on infant and child mortality in urban Nepal. Journal of biosocial science. 1991;23(4):437-43.

23. Pickering AJ, Davis J, Walters SP, Horak HM, Keymer DP, Mushi D, et al. Hands, water, and health: faecal contamination in Tanzanian communities with improved, non-networked water supplies. Environmental science \& technology. 2010;44(9):3267-72.

24. Shaheed A, Orgill J, Montgomery MA, Jeuland MA, Brown J. Why "improved" water sources are not always safe. Bull World Health Organ. 2014;92(4):283-9. Epub 2014/04/05.

25. Seid T, Worku L, Hailu E, Kebede F. FACTORS AFFECTING DRINKING WATER QUALITY FROM SOURCE TO HOME IN TEHULEDERE WOREDA, NORTHEAST ETHIOPIA. Ethiop $J$ Health Sci. 2003;13(2).

26. Israel DH, Awdenegest $\mathrm{M}$. Assessing water quality of rural water supply schemes as a measure of service delivery sustainability: A case study of WondoGenet district, Southern Ethiopia. African Journal of Environmental Science and Technology. 2012;6(5):229-36. 